\title{
Pronectria rhizocarpicola, a new lichenicolous fungus from Switzerland
}

\section{Brackel WV}

Wolfgang von Brackel, Institut für Vegetationskunde und Landschaftsökologie, Georg-Eger-Str. 1b, D-91334 Hemhofen, Germany. -e-mail: wolfgang.von.brackel@ivl-web.de

Brackel WV 2013 - Pronectria rhizocarpicola, a new lichenicolous fungus from Switzerland. Mycosphere 4(5), 926-928, Doi 10.5943/mycosphere/4/5/4

\begin{abstract}
Pronectria rhizocarpicola, a new species of Bionectriaceae is described and illustrated. It is growing parasitically on Rhizocarpon geographicum in the Swiss Alps.
\end{abstract}

Key words - Ascomycota - bionectriaceae - hypocreales

\section{Introduction}

The genus Pronectria currently comprises 44 species, including 2 algicolous and 42 lichenicolous species. Most of the lichenicolous species are living on foliose and fruticose lichens (32 species), only a few on squamulose and crustose lichens (10 species). No species of the genus was ever reported from the host genus Rhizocarpon.

\section{Materials and methods}

Morphological and anatomical observations were made using standard microscopic techniques. Microscopic measurements were made on hand-cut sections mounted in water with an accuracy up to $0.5 \mu \mathrm{m}$. Measurements of ascospores and asci are recorded as (minimum-) $\overline{\mathrm{X}}-\sigma_{\mathrm{x}}-$ $\overline{\mathrm{X}}+\sigma_{\mathrm{x}}$ (-maximum) followed by the number of measurements. The holotype is deposited in $\mathrm{M}$, one isotype in the private herbarium of the author ( $h b$ ivl).

\section{Results}

Pronectria rhizocarpicola Brackel, sp. nov.

Figs 1-2 MycoBank 805068

Etymology - pertaining to the host genus Rhizocarpon.

Diagnosis - Fungus lichenicola in thallo et ascomatibus lichenis Rhizocarpon geographicum crescens. Ascomata immersa, aurantiaca, ca. $250 \mu \mathrm{m}$ diam. et $300 \mu \mathrm{m}$ alta. Asci subcylindrici vel clavati, 8-spori, (55-)59-72(-75) × 8-9(-10) $\mu \mathrm{m}$. Ascosporae ellipsoideae, 1septatae, tenelluliter verruculosae, $(10-) 10.3-12.4(-14) \times(5-) 5.1-5.9(-6.5) \mu \mathrm{m}$.

Holotype - Switzerland, Kanton Bern, Sustenpass, granite rocks, on Rhizocarpon geographicum, $1950 \mathrm{~m}, 46^{\circ} 43^{\prime} 23^{\prime \prime} \mathrm{N}, 08^{\circ} 25^{\prime} 45^{\prime \prime} \mathrm{E}, \mathrm{W}$. v. Brackel, 26.8.2006 (M - holotypus, hb ivl 6623 - isotypus). 
Description - Ascomata completely immersed in the host thallus and apothecia, only the ostiolar region visible, scattered, obpyriform, c. $250 \mu \mathrm{m}$ wide and $300 \mu \mathrm{m}$ high, deep orange in exposed parts, papilla truncate, $80-100 \mu \mathrm{m}$ wide, without hairs; ostiole lined with periphyses c. 1 $\mu \mathrm{m}$ thick; ascomatal wall hyaline to very pale orange, $15-25 \mu \mathrm{m}$ thick, formed by $4-7$ rows of cells; these in cross section 3-9 $31-3 \mu \mathrm{m}$, applanate, thick-walled with narrow lumina on the outer, thin-walled on the inner side of the wall, in surface view of textura angularis with cells of 4-9 $\mu \mathrm{m}$ across, K-, I-, lactic acid -; centrum without or with few oil drops. Paraphyses absent at maturity. Asci subcylindrical to clavate, (6-)8-spored, apically truncate, wall not thickened, only ascoplasm I+ dextroid, $(55-) 59-72(-75) \times 8-9(-10) \mu \mathrm{m}(\mathrm{n}=10)$. Ascospores obliquely monostichous or partly distichous in the asci, ellipsoid, hyaline, 1-septate, with cells only slightly different in size and shape, the upper one being somewhat broader and more rounded, not or slightly constricted at the septum, thick-walled, delicately verruculose at high magnification, rarely with small guttules, $(10-) 10.3-12.4(-14) \times(5-) 5.1-5.9(-6.5) \mu \mathrm{m}, 1 / \mathrm{b}=(1.7-) 1.8-2.3(-2.8)(\mathrm{n}=40)$.

Distribution and host - The new species is known only from the type locality in Switzerland, growing on Rhizocarpon geographicum. The infected regions of the host thallus are discoloured and finally killed.

Discussion - With its orange, immersed perithecia without setae, the lack of persistent interascal filaments, 2-septate ascospores and the $\mathrm{K}$ - reacting peridial wall the new species clearly belongs to the genus Pronectria. All members of the genus are more or less specific to one host species, genus, or closely related genera. No Pronectria species was described from the host genus Rhizocarpon or other members of the family Rhizocarpaceae. Three species on other host genera with similar dimensions of the ascospores have to be compared with the new species: $P$. dillmaniae Zhurb. (on Catapyrenium) is distinguished by intensively orange- or brownish-red and smaller perithecia $[(125-) 200(-250) \times(100-) 150(-200) \mu \mathrm{m}]$. P. diplococca Kocourk. et al. (on Collema) also has smaller perithecia and the ascospores are disintegrating. P. robergei (Mont. \& Desm.) Lowen (on Peltigera and Solorina) seems to be a heterogenous taxon (Zhurbenko 2009) and its ascospore dimensions cover a wide range [8-16 $\times(3-) 4-8 \mu \mathrm{m}]$, including those of the new species. However, the ascospores in $P$. robergei generally are narrowly ellipsoid $[1 / \mathrm{b}=(1.5-) 2.6-3.8(-6.0)]$, the single cells more different from each other with a rounded upper and an attenuated lower one, guttulate, and they are biseriately arranged in the asci. Applying the recently published key to lichenicolous Pronectria species (Khodosovtsev et al. 2012) to the new species leads to no result.

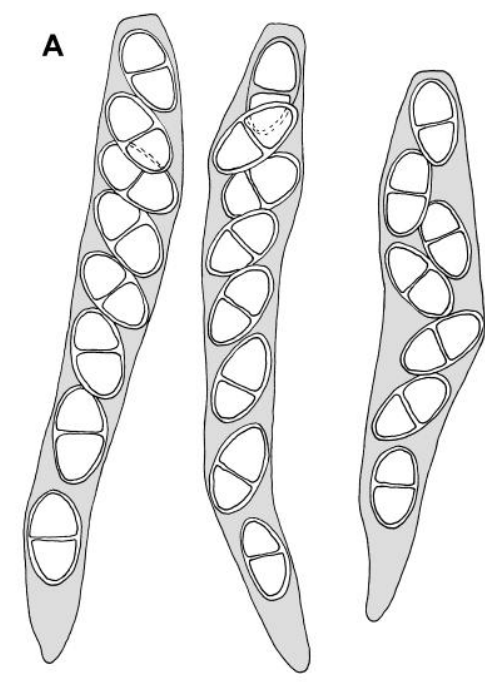

B

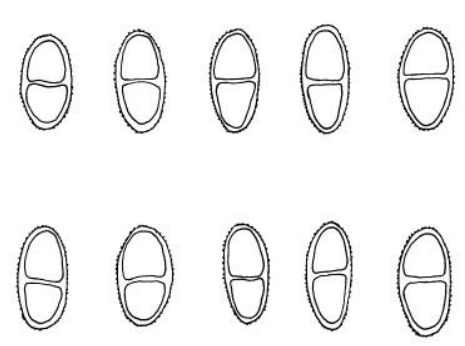

$\underline{10 \mu \mathrm{m}}$

Fig 1 - Pronectria rhizocarpicola (holotypus): A: asci with ascospores. B: ascospores. 


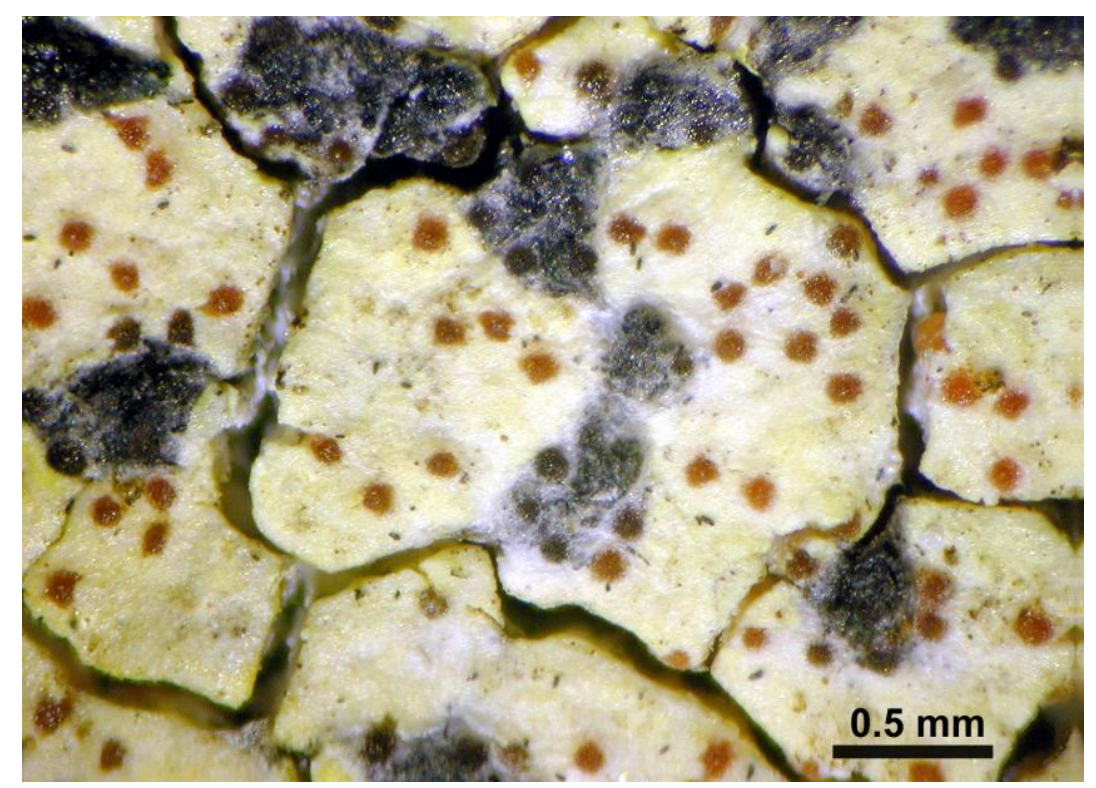

Fig. 2 - Pronectria rhizocarpicola (holotypus): infected part of the thallus of Rhizocarpon geographicum.

\section{References}

Khodosovtsev A, Vondrák J, Naumovich A, Kocourková J, Vondráková O, Motiejunaite J. 2012 Three new Pronectria species in terricolous and saxicolous microlichen communities (Bionectriaceae, Ascomycota). Nova Hedwigia 95, 211-220.

Zhurbenko MP. 2009 - Lichenicolus fungi and lichens from the Holarctic. Part II. Opuscula Philolichenum 7, 121-186. 